\title{
Nutritional Challenges and Opportunities during the Weaning Period and in Young Childhood
}

\author{
Martine S. Alles ${ }^{a} \quad$ Simone R.B.M. Eussen ${ }^{a} \quad$ Eline M. van der Beek ${ }^{b}$ \\ ${ }^{a}$ Nutricia Research, Danone Nutricia Early Life Nutrition, Utrecht, The Netherlands; ${ }^{b}$ Nutricia Research, \\ Danone Nutricia Early Life Nutrition, Singapore, Singapore
}

Key Words

Weaning period $\cdot$ Early years · Feeding habits · Toddler ·

Diet · Nutrition · Transition

\section{Abstract}

The early years of life are a period of very rapid growth and development. In this critical phase, food preferences are formed which carry over into childhood and beyond and foundations are laid for a healthy adult life. Excess energy, imbalances in macronutrient quality, and nutritional deficiencies may form inappropriate nutritional signals, leading to metabolic disturbances and affecting the obesity risk. For instance, the intake of protein and sugar-sweetened beverages in young children has been associated with an increased risk of overweight and obesity. In reality, scientific reports have shown that the dietary intakes of vegetables, a-linolenic acid, docosahexaenoic acid, iron, vitamin $D$, and iodine are low and the intakes of protein, saturated fatty acids, and added sugar are high in young children living in Europe. A focus on improving feeding habits and approaches to support more balanced nutritional intakes early in life may have significant public health benefits.

(c) 2014 S. Karger AG, Basel

\begin{tabular}{ll}
\hline KARGER & $\begin{array}{l}\text { ( } 2014 \text { S. Karger AG, Basel } \\
0250-6807 / 14 / 0644-0284 \$ 39.50 / 0\end{array}$ \\
E-Mail karger@karger.com & $\begin{array}{l}\text { This is an Open Access article licensed under the terms of the } \\
\text { www.karger.com/anm }\end{array}$ \\
$\begin{array}{l}\text { Creative Commons Attribution-NonCommercial 3.0 Un- } \\
\text { ported license (CC BY-NC) (www.karger.com/OA-license), } \\
\text { applicable to the online version of the article only. Distribu- } \\
\text { tion permitted for non-commercial purposes only. }\end{array}$
\end{tabular}

\section{Introduction}

\section{A Phase of Rapid Growth and Development}

The first period of life is characterized by very rapid growth and development. Many organs including the gastrointestinal tract, pancreas, adipose tissue, and brain are still in development throughout infancy and young childhood. The body size doubles and the body weight increases 5 -fold between birth and 3 years of age. Due to the rapid growth and development of the child, the (relative) nutritional requirements are high. Figure 1 gives an overview of the additional nutrient needs of a young child (1-3 years of age) compared to an adult (per kg of body weight) [1].

\section{Relevance of the Transition Period: From 'Milk Only'} to a More Diversified Diet

In this critical phase of life, the child's diet rapidly changes. While it is initially primarily milk based, solids are gradually introduced to the diet and finally the child will eat the family diet. A recent study [2] comparing the early development of BMI between normal weight and overweight children at the age of 8 years clearly showed

Martine S. Alles

Nutricia Research

Danone Nutricia Early Life Nutrition

Uppsalalaan 12, NL-3584 CT Utrecht (The Netherlands)

E-Mail Martine.Alles@ danone.com 


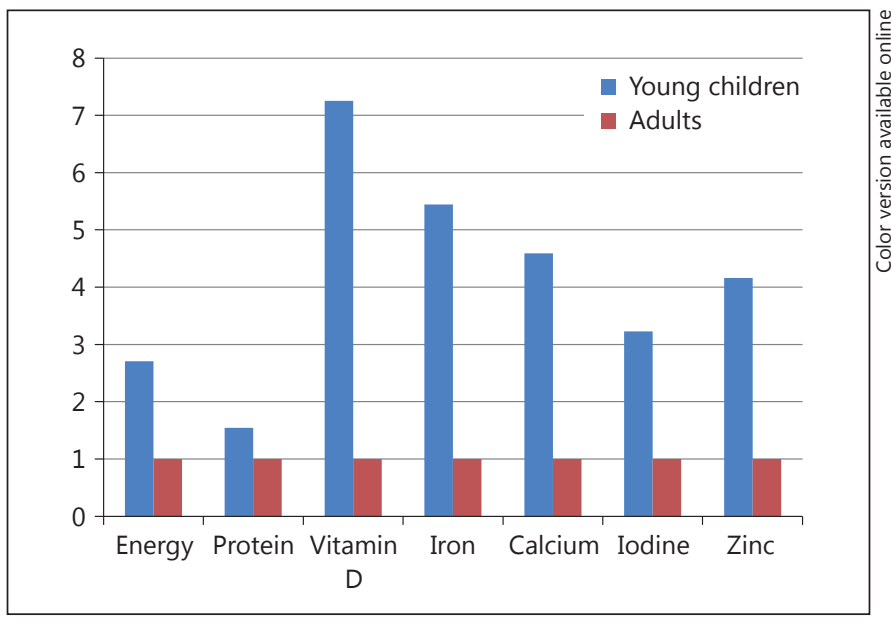

Fig. 1. Additional nutrient needs of a young child compared to an adult $(70 \mathrm{~kg}$ ) per kilogram of body weight. For example, a young child needs 5.5 times more iron per kilogram of body weight compared to an adult.

that BMI development already started to differ significantly between groups during the first year of life and built up consistently after. No evidence of a specific critical period of development of overweight was observed. In a small longitudinal study by Péneau et al. [3], it was suggested that the beneficial effects of breast-feeding on later body fatness could be counteracted by an imbalanced diet after the breast-feeding period, a finding corroborated by recent findings of the Generation R Study [4]. These findings indicate that deviations in the developmental pathways leading to childhood obesity are not limited to any specific period in childhood, which in fact supports a focus on appropriate nutrition and behavioral intervention strategies throughout childhood $[5,6]$. It is thought that the maturation of organs is adapted to the nutritional environment in this critical period of development. An excess of energy, imbalances in macronutrient quality, and nutritional deficiencies are negative nutritional signals which may lead to, for example, metabolic disturbances or the development of obesity [7-10].

Early life is also a crucial phase for the development of healthy eating habits. With repeated exposure and an available variety, the child learns to accept many different tastes [11-13] and these preferences subsequently carry over into childhood and beyond [14-17].

In this review, we discuss the nutritional reality of older infants (aged 6 months to 1 year) and young children (aged 1-3 years) in Europe and the possible consequences of different nutritional challenges for metabolic development.

\section{Methodology}

To obtain information on the diet and nutrient intakes of young children in European countries, an extensive literature review was conducted. This literature review included structured searches for relevant published literature using a range of health care-related databases (PubMed, MEDLINE, Pascal, and Web of Science) as well as grey literature obtained from international and national organizations [e.g. the Food and Agriculture Organization, UNICEF, the World Health Organization (WHO), the US Agency for International Development, the CIA World Factbook, the World Bank, and websites of ministries of health and NGOs].

The information on diet and nutrient intakes obtained from this literature review was compared to nutritional recommendations. Reference values given by the European Food Safety Authority (EFSA) [18-21] were used when available; otherwise, intakes were compared to recommendations of the Nordic Council of Ministers [1].

\section{Results}

\section{Nutritional Intakes in Late Infancy and Young Childhood}

The literature review showed that the dietary intakes of vegetables, $\mathrm{n}-3$ fatty acids, iron, vitamin $\mathrm{D}$, and iodine were consistently lower in older infants and young children, whereas the intakes of protein, saturated fatty acids (SFA), sodium, and free sugar were often higher than recommended.

\section{Vegetables}

Vegetables are important sources of vitamins and minerals, and diets rich in vegetables are known to help protect against disease [22, 23]. The recommended amounts of vegetables differ between countries but are generally around $75-100 \mathrm{~g}$ at 1 year and increase to about $125-150 \mathrm{~g}$ at around 3 years of age $[24,25]$.

Vegetables tend to be less well accepted by infants and young children, most likely due to their innate liking for sweet tastes. We found that vegetable intakes in European infants and young children were often lower than the recommendations (fig. 2) [24-30].

\section{n-3 Fatty Acids}

The dietary recommendations of the EFSA for essential fatty acids (EFA) are [18]:

- $\alpha$-linolenic acid (ALA): adequate intake of $0.5 \%$ of energy (en\%)

- linoleic acid (LA): adequate intake of 4 en\%

- docosahexaenoic acid (DHA): adequate intake of 100 $\mathrm{mg} /$ day for infants and young children (aged $<2$ years) 
Fig. 2. Vegetable intake of older infants and young children in European countries [2430] compared to recommendations.
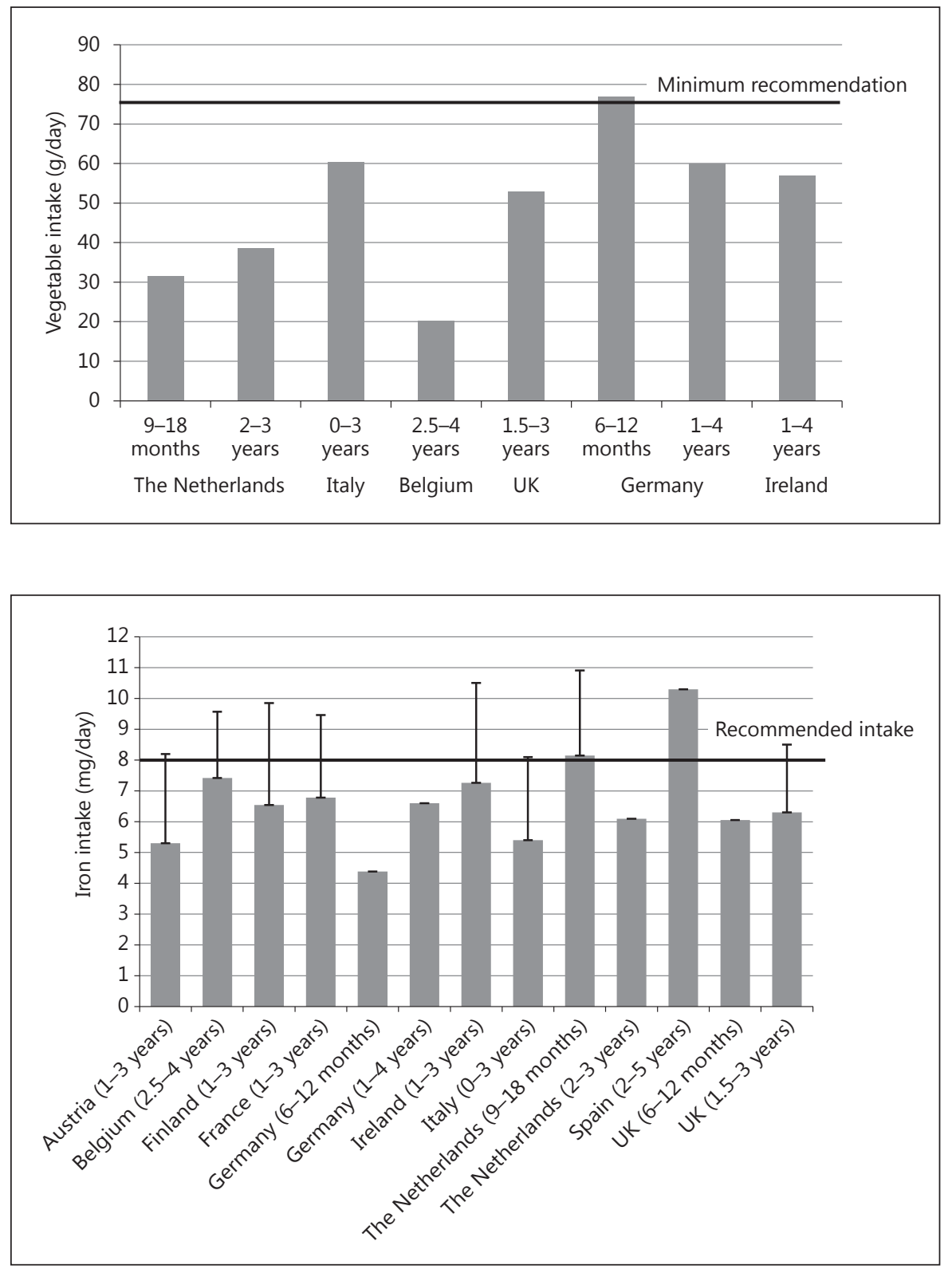

Fig. 3. Iron intake of older infants and young children in European countries [25, 28-30, 33-41] compared to recommendations [1].
- DHA and eicosapentaenoic acid (EPA): adequate intake of $250 \mathrm{mg}$ for children $>2$ years of age.

The limited information found in the public domain on the intake of EFA indicates that intakes are below or close to the lower end of the recommended intake. Especially intakes of EPA and DHA are far below the recommendations. For instance, in Belgium, children aged 2.53 years consumed 0.5 en $\%$ ( $0.8 \mathrm{~g}$ ) ALA, 4 en $\%$ LA, $20 \mathrm{mg}$ EPA, and $40 \mathrm{mg}$ DHA per day. Austrian children aged 3-6 years consumed $0.5 \mathrm{en} \%$ ( $0.8 \mathrm{~g})$ ALA, $20 \mathrm{mg}$ EPA, and $80 \mathrm{mg}$ DHA per day [18].

\section{Iron}

Infants and children have higher iron requirements during the period of fast growth [31], but many older infants and young children do not consume large quantities of iron-rich foods such as red meat and green leafy vegetables. A modeling study even concluded that it is impossible to achieve the recommended iron intakes with a diet completely conforming to dietary guidelines for infants/young children [32].

The average daily iron intake of older infants and young children in European countries was found to be 
Fig. 4. Vitamin D intake of older infants and young children in European countries $[25,29,30,33-37,39-41]$ compared to recommendations [1].

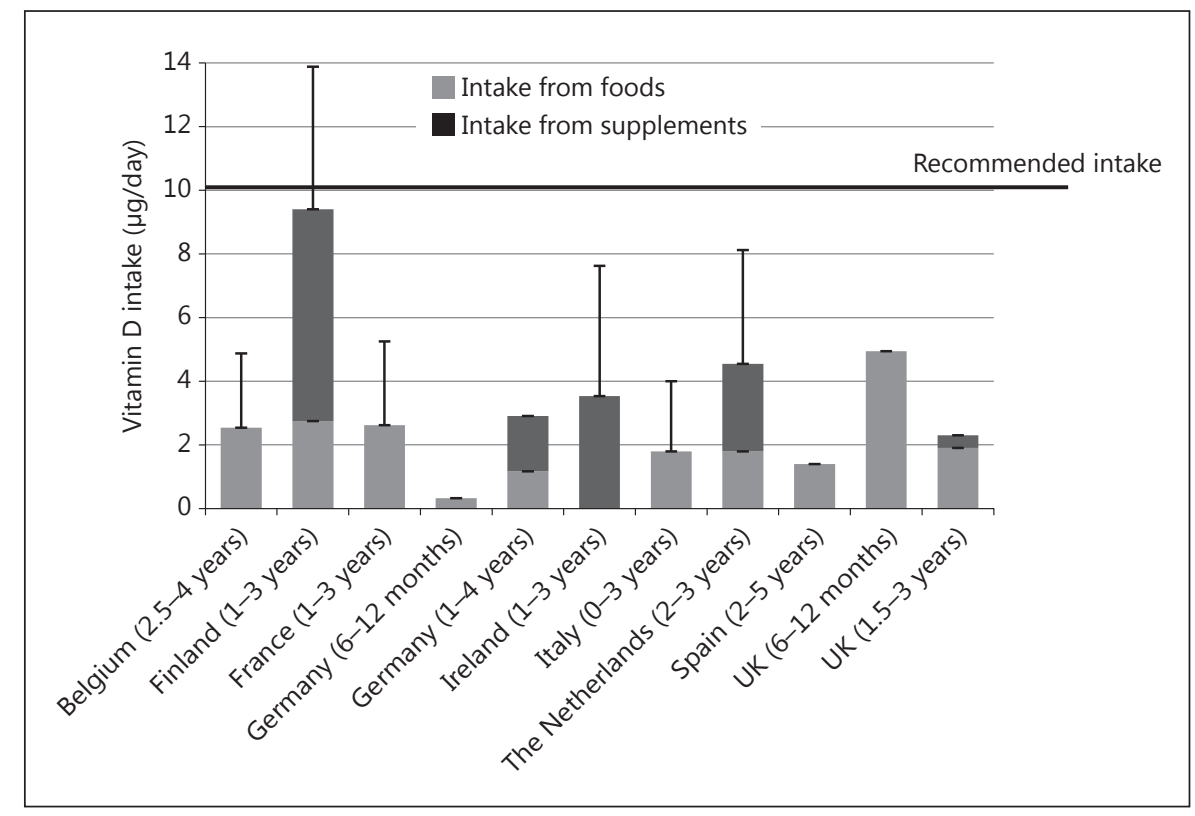

around 6-7 mg/day [25, 28-30,33-41] and thus was only slightly lower than the recommended value of $8 \mathrm{mg} /$ day (fig. 3) [1].

Despite the small intake gap, an inadequate iron intake may still be relevant as the brain is in rapid development during this period of life. Symptoms of iron deficiency (anemia) may be fatigue, lack of energy, headache, trouble sleeping, loss of appetite, paleness, reduced resistance to infection, and poor memory. In 6-month-old infants, iron deficiency anemia has been found to be associated with adverse effects on important measures of central nervous system development at 12 and 18 months [42].

\section{Vitamin D}

As indicated above, young children need 7 times more vitamin D per kilogram of body weight (fig. 1) and 2.5 times more vitamin D per $100 \mathrm{kcal}$ of food intake compared to adults [1]. Inadequate vitamin D intakes (fig. 4) $[25,29,30,33-37,39-41]$ and a deficient vitamin D status in older infants and young children have been observed in virtually all countries in Europe [43-46]. The current consensus based on these findings is that vitamin D should be regarded as a key nutrient for these age groups. Most foods only contain traces of vitamin D, with the exception of oily fish, which is, however, not frequently consumed by older infants and young children. A number of Western countries recommend vitamin D supplements, but compliance with the use of supplements has been found to be low, i.e. $10-50 \%$ [47-50].

Nutritional Challenges and Opportunities during Weaning and in Young Childhood
Iodine

Inadequate iodine intakes and a deficient iodine status have been observed in young children in several European countries, among which are Germany, Austria, France, the Netherlands, and Turkey [25, 38, 51, 52], whereas in other countries (e.g. the UK) the daily iodine intakes meet the recommended value of $70-90 \mu \mathrm{g}[53$, 54]. This could be related to the iodine levels (declared) in cow's milk, which vary greatly throughout the different seasons and between regions. For example, reference values for cow's milk in different countries range from 3.3 $\mu \mathrm{g} / 100 \mathrm{~g}$ in Germany, through $7 \mu \mathrm{g} / 100 \mathrm{~g}$ in the Netherlands, and up to $31 \mu \mathrm{g} / 100 \mathrm{~g}$ in the UK.

\section{Protein}

From 0.5 to 3 years of age, the required en\% from protein decreases from around 6 to $4.5 \mathrm{en} \%$ as recommended by the EFSA [20]. The EFSA also stated that the current data are insufficient to establish a tolerable upper intake level for protein and concluded that intakes of up to twice the requirement $(\sim 10 \mathrm{en} \%)$ are regularly consumed from mixed diets and are to be considered safe [20]. Agostoni et al. [55] stated in a commentary paper by the ESPGHAN Committee on Nutrition that, although not entirely consistent, protein intakes $\geq 16$ en $\%$ between the ages of 8 and 24 months may be associated with later overweight, whereas such associations were not seen with protein intakes $<15$ en\%. Protein intake levels in older infants and young children were found to be close to this proposed upper limit 
Fig. 5. Protein intake of older infants and young children in European countries [24, $25,28-30,33-35,37-41]$ compared to the average requirements [20] and the proposed upper limit [55].
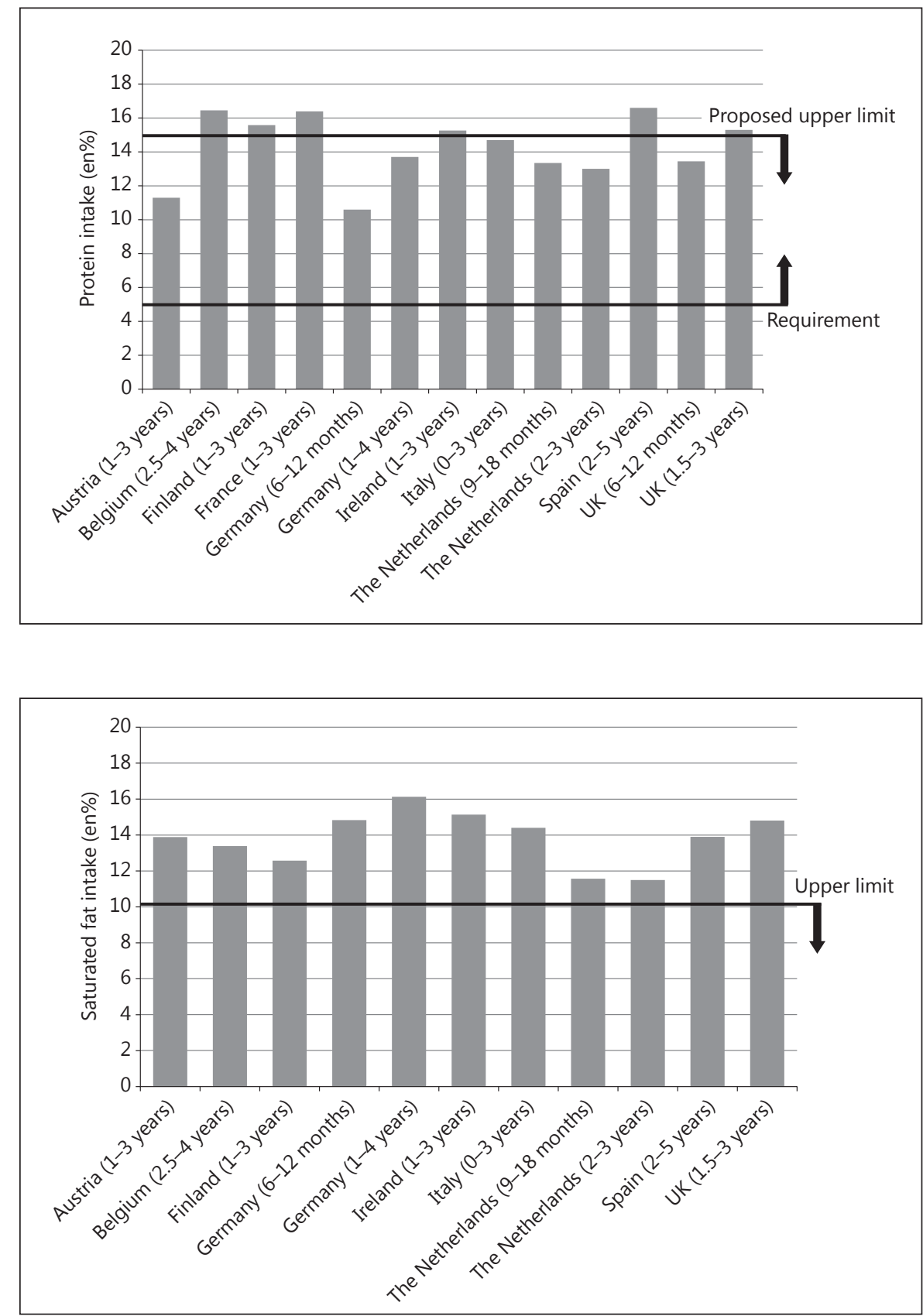

Fig. 6. SFA intake of older infants and young children in European countries [24, $25,28-30,33-35,37-39]$ compared to the upper limit $[1,18]$.
Saturated Fatty Acids

In European countries, the average intake of SFA in older infants and young children is 11-13 en\%, which exceeds the recommended maximum intake level of $10 \mathrm{en} \%$ (fig. 6) [24, 25, 28-30, 33-35, 37-39].

Low dietary intakes of SFA, i.e. levels $<10 \mathrm{en} \%$ and preferably lower $[1,18]$, are recommended to reduce the long-term risk of heart disease [18]. Even at a young age, high dietary intakes of SFA have been shown to increase 
Fig. 7. Sodium intake of older infants and young children in European countries [25, $29,30,33,34,37-41]$ compared to the upper limits (UL) $[1,18]$.

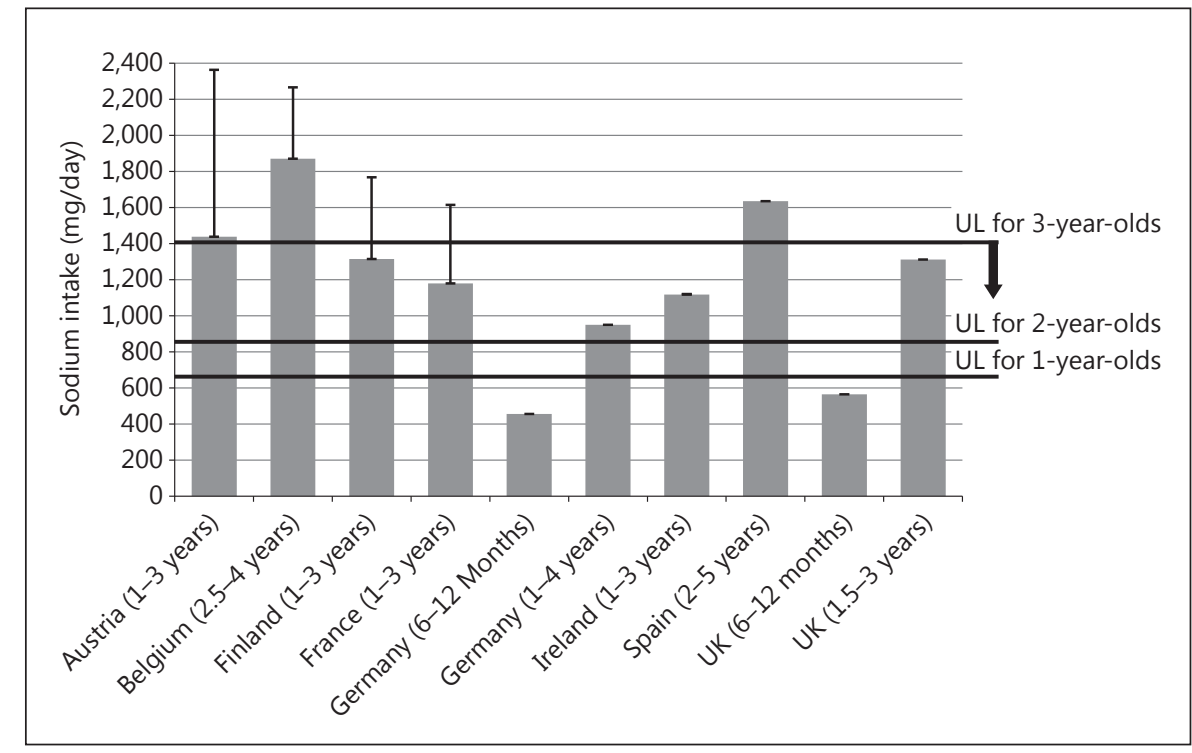

plasma total and LDL cholesterol concentrations and could enhance vascular lipid deposition and the occurrence of early vascular lesions [57-60]. In the Special Turku Coronary Risk Factor Intervention Project (STRIP), 1,000 healthy infants were randomized to a lowsaturated-fat, low-cholesterol diet counseling group and a control group and were followed every 6-12 months throughout childhood. The results showed that cholesterol levels were significantly reduced throughout childhood and endothelial function was improved in 11-yearold boys randomized to the intervention group. There were no effects on growth, language skills, or motor functioning $[58,60]$.

\section{Sodium}

The habitual intake of sodium for all populations across Europe, including young children, is high (fig. 7) $[25,29,30,33,34,37-41]$ and exceeds the amounts required for normal function [1]. The sodium intakes of 1to 3-year-olds range from $950 \mathrm{mg}$ in Germany to more than $1,800 \mathrm{mg}$ in Belgium and exceed the recommendation of $0.5 \mathrm{~g} / \mathrm{MJ}$ for 1 - and 2-year-olds. From 2 years of age onwards, the Nordic Council of Ministers set an upper limit of 1,400 mg of sodium per day, which is exceeded in both Belgium and Spain, i.e. the countries that included slightly older children.

Already at the beginning of early childhood, the systolic blood pressure rises with increasing sodium intakes. Blood pressure measured in childhood predicts the blood pressure level and even the development of early atherosclerosis in adulthood [1]. It may be important to limit the sodium intakes in infancy and childhood to prevent children from becoming accustomed to and having a preference for a diet with a relatively high sodium content later in life.

\section{Free Sugars}

The different definitions that have been used to assess (added) sugar intake in the population make it difficult to compare sugar intake levels among European children. For example, in the UK the term 'non-milk extrinsic sugar' is used [30], whereas in Finland they refer to 'sucrose' [33] and in the Netherlands to 'sugar and confectionery' [24]. However, generally, older infants and young children consume much more free sugars, i.e. sugars that are added to food by the manufacturer or consumer, as well as sugars that are naturally present in honey, syrups, and fruit juices, as the recommended $10 \mathrm{en} \%$ as recently proposed by the WHO. The WHO even suggested that a reduction to $<5$ en\% would have additional benefits [61]. For example, in Irish preschoolers the intake of sugar is $50 \mathrm{~g} /$ day, which equals about 19 en\% [29] compared to the recommended 5-10 en\% (fig. 8) [24, 29, 30, 33].

Free sugars are not essential for infants and young children as their diet contains many sources of other carbohydrates.

It is important to limit the intake of free sugars in the diet of infants and children for 3 reasons.

Firstly, free sugars are merely added for their sweet taste. Early life is a sensitive period for the development of food preferences that carry over into adulthood, and 
Fig. 8. Free sugar intake of older infants and young children in European countries $[24,29,30,33]$.

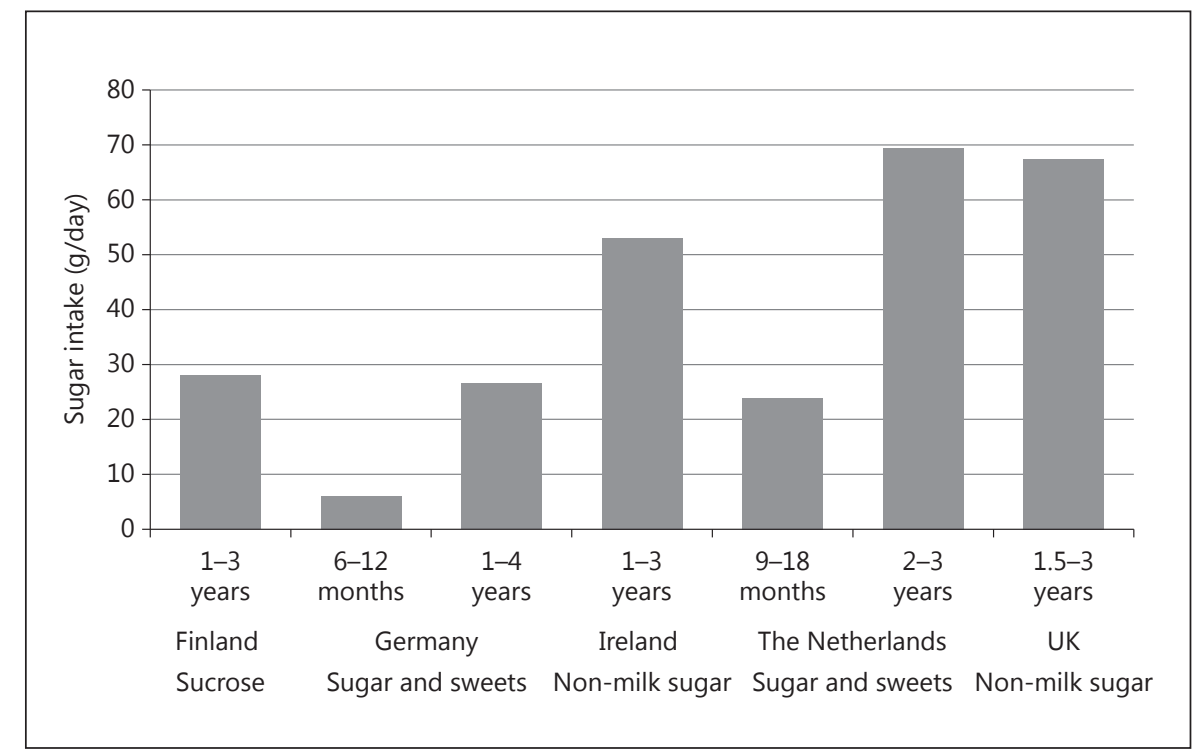

exposure to sweet tastes early in life may lead to a preference for sweet tastes later in life [16, 62]. Secondly, sweet products generally have a poor nutritional profile, i.e. they contain so-called 'empty calories', and it has been demonstrated that children with a high en $\%$ coming from sugars have lower intakes of micronutrients (i.e. calcium, zinc, thiamin, riboflavin, niacin, and folate) and dietary fiber [63-68]. Thirdly, products containing free sugars are known to increase the risk of dental caries in children [69]. The first step in the pathogenesis of dental caries is infection with the bacterial strain Streptococcus mutans [70], and it has been shown that this bacterium produces more acid with sucrose and glucose compared to milk sugar lactose $[71,72]$. Finally, the consumption of sugar, and especially sugar-sweetened beverages, has been linked to the onset of childhood obesity [73].

\section{Increased Risk of Childhood Obesity}

The results of our evaluation showed a number of discrepancies between the recommendations for these young age groups and the real nutrient intakes in many European countries. Especially the imbalances in macronutrients, that may also drive some of the reported micronutrient deficiencies, can be a concern. There has been a dramatic increase in the prevalence of childhood overweight and obesity in the last 3 decades worldwide [74], and this may be associated with higher prevalences of cardiovascular and metabolic diseases later in life [75]. Although initially 'developmental origin of adult health and disease' (DOHaD) studies almost exclusively focused on the role of the fetal environment noncommunicable disease risk, it has become increasingly acknowledged that the window of programming extends into the (early) postnatal period [76-78].

Imbalances in nutrient intake may be relevant as they may challenge optimal organ growth and development of function during this postnatal period. The development and (functional) maturation of many (metabolic) organs including the gastrointestinal tract [78], brain [79], pancreas [80], and adipose tissue [81] continue for a considerable time after birth. For instance, adult differences in adipose cell numbers between lean and obese people gradually develop during childhood, already showing a 2 -fold difference in the number of cells at the age of 2 years [82].

Some specific epidemiological and animal findings also support the relevance of the postnatal period as an independent contributor to the later disease risk. Initial studies of the Dutch famine showed a clear distinction between early pregnancy and late pregnancy exposure and later (disease) outcomes [83]. However, also women exposed to the Dutch famine between the ages of 0 and 9 years showed increased type 2 diabetes and overweight compared to unexposed women $[84,85]$. These observational data are supported by an analysis of individual growth trajectories showing that weight gain between 0 and 2 years of age is most predictive of the later adiposity risk [86]. Recent data from the Generation R Study confirm the specific contribution of postnatal growth to the risk of overweight and obesity at the age of 6 years [87]. 
Animal studies have shown that [88] low protein in the postnatal diet reduces the adult fat mass, whereas the same diet during the fetal period is associated with adverse outcomes in adulthood. Similarly, moderate energy restriction during lactation has been shown to protect against enhanced adult fat accumulation in rats, whereas energy restriction during gestation has had the opposite effect [89]. These observations illustrate that growth depends on different fuels in fetal and postnatal life and is related to the timing of the development of individual organs and their nutritional needs during these different stages. Adequate nutritional intakes to support these different periods of organ growth and functional maturation are essential to achieving optimal organ capacity.

\section{The Toddler Period: Diet and Obesity Risk}

An important part of the daily energy intake during the first 3 years of life is derived from dietary fat. During the first 4-6 months of life, human milk (or infant milk formula) is the sole source of nutrition for the infant, providing $40-50 \mathrm{en} \%$ as fat. Dietary lipids provide energy for growth, supply the EFA LA (C18:2 n-6) and ALA (C18:3 $\mathrm{n}-3)$, and ensure adequate absorption of fat-soluble vitamins. Between 6 months and 2 years of age, the WHO recommends 30-40 en\% from fat, although it was recently suggested that the energy derived from fat should be gradually reduced to a maximum of $30 \%$ to better match energy requirements and reduce the weight gain velocity according to the latest reference growth standards.

Observational data have linked low fat intakes at 10 months and 2 years of age to increased trunk body fat deposition and higher leptin resistance in young adulthood, supporting the significance of fat as the main energy provider in the early diet [90]. These data also clearly illustrate that the nutritional requirements to support optimal growth and development at this age differ from those advised for older children and adolescents.

A high protein intake at the ages of 12 and 18-24 months was independently related to a higher BMI and percentage of body fat and to a higher risk of having a BMI or percentage of body fat above the 75 th percentile at the age of 7 years. The quality of the protein may be relevant as well, as both total protein and a high intake of animal but not vegetable protein were associated with increased body fat at 7 years [91, 92].

Studies conducted in populations of children have demonstrated positive associations between the intake of sugar and BMI development [93-95]. However, the number of studies investigating the relationship between the total sugar intake in children and the obesity risk is small, likely related to the fact that limited sugar intake data are available.

Frequent exposure to foods and beverages containing sugar may have longer-term effects that could contribute to the risk of developing childhood obesity, but not all scientific evidence is consistent. In infants with a poor nutrient status, the intake of products high in sugar has been associated with a potential risk of developing micronutrient deficiencies due to their lower nutrient density compared to products lower in sugar [63-68].

\section{Discussion and Conclusion}

In summary, the dietary intakes of vegetables, n-3 fatty acids, iron, vitamin $\mathrm{D}$, and iodine are low and the intakes of protein, SFA, sodium, and free sugar are high in older infants and young children living in Europe. These findings are relevant taking into account the specific nutrient needs during these early stages of life, supporting the optimal development of organs and their function. Possible long-term consequences of these nutrient gaps could affect the development of a healthy taste and eating habits as well as the body composition.

For this review, we were dependent on the available dietary intake data across Europe. Several European countries, such as Norway, Portugal, and Switzerland, lack national data on infants' and children's food and nutrient intakes and surveys are often out of date: 8 out of 13 dietary surveys are more than 5 years old. Moreover, the methodologies of the different dietary surveys differ from country to country and are therefore difficult to compare. For example, dietary surveys differed in age categories, dietary assessment methodology, sample size, and definitions of nutrients. Some surveys were limited to a specific geographical area or population and were not necessarily representative of the entire country. For example, the Belgian survey was done in Flanders, Belgium, only.

In order to obtain a clear overview of the nutritional reality of young European children, high-quality, representative food and nutrient intake data are needed. Dietary surveys should be performed on a regular basis in each European country to follow longitudinal trends in food and nutrient intakes.

\section{Disclosure Statement}

All authors are full time employees of Danone Nutricia Early Life Nutrition.
Nutritional Challenges and Opportunities during Weaning and in Young Childhood
Ann Nutr Metab 2014;64:284-293 DOI: $10.1159 / 000365036$ 


\section{References}

1 Nordic Council of Ministers: Nordic nutrition recommendations 2012 - integrating nutrition and physical activity. 2014. http:// www.norden.org/en/publications/publikationer/2014-002 (accessed May 5, 2014).

2 Willers SM, et al: BMI development of normal weight and overweight children in the PIAMA study. PLoS One 2012;7:e39517.

-3 Péneau S, Hercberg S, Rolland-Cachera MF: Breastfeeding, early nutrition, and adult body fat. J Pediatr 2014;164:1363-1368.

-4 Durmus B, et al: General and abdominal fat outcomes in school-age children associated with infant breastfeeding patterns. Am J Clin Nutr 2014;99:1351-1358.

5 Lampl M, Veldhuis JD, Johnson ML: Saltation and stasis: a model of human growth. Science 1992;258:801-803.

-6 Scholtens S, et al: Breastfeeding, weight gain in infancy, and overweight at seven years of age: the prevention and incidence of asthma and mite allergy birth cohort study. Am J Epidemiol 2007;165:919-926.

7 Wyrwoll CS, et al: Prevention of programmed hyperleptinemia and hypertension by postnatal dietary omega-3 fatty acids. Endocrinology 2006;147:599-606.

8 Erhuma A, et al: Prenatal exposure to undernutrition and programming of responses to high-fat feeding in the rat. Br J Nutr 2007;98: 517-524.

-9 Singhal A, et al: Nutrition in infancy and longterm risk of obesity: evidence from 2 randomized controlled trials. Am J Clin Nutr 2010;92: 1133-1144.

10 Velkoska E, Cole TJ, Morris MJ: Early dietary intervention: long-term effects on blood pressure, brain neuropeptide $\mathrm{Y}$, and adiposity markers. Am J Physiol Endocrinol Metab 2005;288:E1236-E1243.

11 Mennella JA, Griffin CE, Beauchamp GK: Flavor programming during infancy. Pediatrics 2004;113:840-845.

12 Beauchamp GK, Mennella JA: Early flavor learning and its impact on later feeding behavior. J Pediatr Gastroenterol Nutr 2009; 48(suppl 1):S25-S30.

13 Liem DG, de Graaf C: Sweet and sour preferences in young children and adults: role of repeated exposure. Physiol Behav 2004;83:421429.

14 Beauchamp GK, Moran M: Dietary experience and sweet taste preference in human infants. Appetite 1982;3:139-152.

15 Beauchamp GK, Moran M: Acceptance of sweet and salty tastes in 2-year-old children. Appetite 1984;5:291-305.

16 Liem DG, Mennella JA: Sweet and sour preferences during childhood: role of early experiences. Dev Psychobiol 2002;41:388-395.

17 Pepino MY, Mennella JA: Factors contributing to individual differences in sucrose preference. Chem Senses 2005;30(suppl 1):i319i320.
18 EFSA Panel on Dietetic Products, Nutrition and Allergies: Scientific opinion on dietary reference values for fats, including saturated fatty acids, polyunsaturated fatty acids, monounsaturated fatty acids, trans fatty acids, and cholesterol. EFSA J 2010;8:1461.

19 EFSA Panel on Dietetic Products, Nutrition and Allergies: Scientific opinion on dietary reference values for carbohydrates and dietary fibre. EFSA J 2010;8:1462.

20 EFSA Panel on Dietetic Products, Nutrition and Allergies: Scientific opinion on dietary reference values for protein. EFSA J 2012;10: 2257.

21 EFSA Panel on Dietetic Products, Nutrition and Allergies: Scientific opinion on dietary reference values for energy. EFSA J 2013;11: 3005.

22 Dauchet L, Amouyel P, Dallongeville J: Fruit and vegetable consumption and risk of stroke: a meta-analysis of cohort studies. Neurology 2005;65:1193-1197.

23 Dauchet L, et al: Fruit and vegetable consumption and risk of coronary heart disease: a meta-analysis of cohort studies. J Nutr 2006; 136:2588-2593.

24 Ocké MC, et al: Dutch National Food Consumption Survey - Young Children. Bilthoven, RIVM, 2005/2006.

25 Deutsche Gesellschaft für Ernährung: Ernährungsbericht. Bonn, Bundesministeriums für Ernährung Landwirtschaft und Verbraucherschutz, 2008.

26 Leclercq C, et al: The Italian National Food Consumption Survey INRAN-SCAI 200506: main results in terms of food consumption. Public Health Nutr 2009;12:2504-2532.

27 Huybrechts I, et al: Food intakes by preschool children in Flanders compared with dietary guidelines. Int J Environ Res Public Health 2008;5:243-257.

28 Breedveld BC, Hulshof KFAM: Zo eten jonge peuters in Nederland 2002: resultaten van het Voedingsstoffen Inname Onderzoek (VIO). The Hague, Voedingscentrum, 2002.

29 Walton J (ed): National Pre-School Nutrition Survey - Summary Report on: Food and Nutrient Intakes, Physical Measurements and Barriers to Healthy Eating. Irish Universities Nutrition Alliance, Cork, 2012.

30 Bates B, Lennox A, Swan G (eds): National Diet and Nutrition Survey Year 1 and 2 of Rolling Program, 2008-2010. London, NatCen/UCL/MRC, 2011.

31 Domellof M: Iron requirements in infancy. Ann Nutr Metab 2011;59:59-63.

32 Ferguson EL, et al: Design of optimal foodbased complementary feeding recommendations and identification of key 'problem nutrients' using goal programming. J Nutr 2006; 136:2399-2404

33 Kyttala P, et al: Food consumption and nutrient intake in Finnish 1-6-year-old children. Public Health Nutr 2010;13:947-956.
34 Fantino M, Gourmet E: Nutrient intakes in 2005 by non-breast fed French children of less than 36 months (in French). Arch Pediatr 2008; 15:446-455.

35 Sette S, et al: The third Italian National Food Consumption Survey, INRAN-SCAI 200506. 1. Nutrient intakes in Italy. Nutr Metab Cardiovasc Dis 2011;21:922-932.

36 Ocké MC, van Rossum CTM, Fransen HP, Buurma EJM, et al: Dutch National Food Consumption Survey - Young Children 2005/2006. Bilthoven, National Institute for Public Health and the Environment, 2008.

-37 Serra-Majem L, et al: Nutrient adequacy in Spanish children and adolescents. Br J Nutr 2006;96(suppl 1):S49-S57.

38 Veitl V: Ernährungssituation von Kleinkindern. J Ernährungsmed 2006;8:6-12.

39 Huybrechts I, De Henauw S: Energy and nutrient intakes by pre-school children in Flanders-Belgium. Br J Nutr 2007;98:600-610.

40 Marriott LD, et al: What do babies eat? Evaluation of a food frequency questionnaire to assess the diets of infants aged 12 months. Public Health Nutr 2009;12:967-972.

41 Marriott LD, et al: What do babies eat? Evaluation of a food frequency questionnaire to assess the diets of infants aged 6 months. Public Health Nutr 2008;11:751-756.

42 Roncagliolo M, et al: Evidence of altered central nervous system development in infants with iron deficiency anemia at 6 mo: delayed maturation of auditory brainstem responses. Am J Clin Nutr 1998;68:683-690.

43 Braegger C, et al: Vitamin D in the Healthy European Paediatric Population. J Pediatr Gastroenterol Nutr 2013;56:692-701.

44 Cashman KD: Vitamin D in childhood and adolescence. Postgrad Med J 2007;83:230235.

45 Holick MF: Vitamin D deficiency. N Engl J Med 2007;357:266-281.

46 Gordon CM, et al: Prevalence of vitamin D deficiency among healthy infants and toddlers. Arch Pediatr Adolesc Med 2008;162: 505-512.

47 de Nooijer J, Jansen R, van Assema P: The use of implementation intentions to promote vitamin D supplementation in young children. Nutrients 2012;4:1454-1463.

48 Marjamaki L, et al: Use of vitamin D and other dietary supplements by Finnish children at the age of 2 and 3 years. Int J Vitam Nutr Res 2004;74:27-34.

49 Pludowski P, et al: Vitamin D supplementation and status in infants: a prospective cohort observational study. J Pediatr Gastroenterol Nutr 2011;53:93-99.

50 Taylor JA, Geyer LJ, Feldman KW: Use of supplemental vitamin D among infants breastfed for prolonged periods. Pediatrics 2010;125:105-111. 
51 Pouessel G, et al: Iodine nutritional status and risk factors for iodine deficiency in infants and children of the French North department (in French). Arch Pediatr 2003;10:96-101.

52 Verkaik-Kloosterman J, van 't Veer P, Ocke MC: Reduction of salt: will iodine intake remain adequate in the Netherlands? Br J Nutr 2010;104:1712-1718.

53 British Nutrition Foundation: National Diet and Nutrition Survey rolling programme year 1 and 2 (combined) results. 2011. http:// www.nutrition.org.uk/nutritioninthenews/ new-reports/ndns-year-2 (accessed January 4, 2013).

54 Weker H, et al: Analysis of nutrition of children aged 13-36 months in Poland - A Nation-wide study. Medycyna Wieka Roswojowego 2011;XV:224-231.

55 Agostoni C, et al: Complementary feeding: a commentary by the ESPGHAN Committee on Nutrition. J Pediatr Gastroenterol Nutr 2008;46:99-110.

56 Hornell A, et al: Protein intake from 0 to 18 years of age and its relation to health: a systematic literature review for the 5th Nordic Nutrition Recommendations. Food Nutr Res 2013, DOI: 10.3402/fnr.v57i0.21083.

57 Strong JP, et al: Early lesions of atherosclerosis in childhood and youth: natural history and risk factors. J Am Coll Nutr 1992;11:51S$54 \mathrm{~S}$.

58 Magnussen CG, et al: When and how to start prevention of atherosclerosis? Lessons from the Cardiovascular Risk in the Young Finns Study and the Special Turku Coronary Risk Factor Intervention Project. Pediatr Nephrol 27:1441-1452.

59 Hooper L, et al: Reduced or modified dietary fat for preventing cardiovascular disease. Cochrane Database Syst Rev 2012;5:CD002137.

60 Niinikoski H, et al: Impact of repeated dietary counseling between infancy and 14 years of age on dietary intakes and serum lipids and lipoproteins: the STRIP study. Circulation 2007;116:1032-1040.

61 World Health Organization: Draft guideline - sugars intake for adults and children. 2014. http://www.who.int/nutrition/sugars_public_consultation/en/.

62 Mennella JA, Beauchamp GK: Flavor experiences during formula feeding are related to preferences during childhood. Early Hum Dev 2002;68:71-82.

63 Ruottinen S, et al: High sucrose intake is associated with poor quality of diet and growth between 13 months and 9 years of age: the special Turku Coronary Risk Factor Intervention Project. Pediatrics 2008;121:e1676e1685.

64 Alexy U, Sichert-Hellert W, Kersting M: Associations between intake of added sugars and intakes of nutrients and food groups in the diets of German children and adolescents. $\mathrm{Br}$ J Nutr 2003;90:441-447.
65 Erkkola M, et al: Sucrose in the diet of 3-yearold Finnish children: sources, determinants and impact on food and nutrient intake. $\mathrm{Br} \mathrm{J}$ Nutr 2009;101:1209-1217.

66 Joyce T, Gibney MJ: The impact of added sugar consumption on overall dietary quality in Irish children and teenagers. J Hum Nutr Diet 2008;21:438-450.

67 Kranz S, Smiciklas-Wright H, Francis LA: Diet quality, added sugar, and dietary fiber intakes in American preschoolers. Pediatr Dent 2006;28:164-171, discussion 192-198.

68 Kranz S, et al: Adverse effect of high added sugar consumption on dietary intake in American preschoolers. J Pediatr 2005;146: 105-111.

69 Ruottinen S, et al: Sucrose intake since infancy and dental health in 10-year-old children. Caries Res 2004;38:142-148.

70 Arnold DL, et al: Canadian saccharin study. Science 1977; 197:320.

71 Haukioja A, Soderling E, Tenovuo J: Acid production from sugars and sugar alcohols by probiotic lactobacilli and bifidobacteria in vi tro. Caries Res 2008;42:449-453.

72 Moynihan P, Petersen PE: Diet, nutrition and the prevention of dental diseases. Public Health Nutr 2004;7:201-226.

73 de Ruyter JC, et al: A trial of sugar-free or sugar-sweetened beverages and body weight in children. N Engl J Med 2012;367:1397-1406.

74 Wang Y, Lobstein T: Worldwide trends in childhood overweight and obesity. Int J Pediatr Obes 2006;1:11-25.

75 Kelly AS, et al: Severe obesity in children and adolescents: identification, associated health risks, and treatment approaches: a scientific statement from the American Heart Association. Circulation 2013;128:1689-1712.

76 Singhal A, Lucas A: Early origins of cardiovascular disease: is there a unifying hypothesis? Lancet 2004;363:1642-1645.

77 Guilloteau P, et al: Adverse effects of nutritional programming during prenatal and early postnatal life, some aspects of regulation and potential prevention and treatments. J Physiol Pharmacol 2009;60(suppl 3):17-35.

78 Le Huerou-Luron I, Blat S, Boudry G: Breastv. formula-feeding: impacts on the digestive tract and immediate and long-term health effects. Nutr Res Rev 2010;23:23-36.

79 Alamy M, Bengelloun WA: Malnutrition and brain development: an analysis of the effects of inadequate diet during different stages of life in rat. Neurosci Biobehav Rev 2012;36: 1463-1480.

80 Fowden AL, Hill DJ: Intra-uterine programming of the endocrine pancreas. Br Med Bull 2001;60:123-142.
81 Symonds ME, et al: Adipose tissue development - impact of the early life environment. Prog Biophys Mol Biol 2011;106:300-306.

82 Spalding KL, et al: Dynamics of fat cell turnover in humans. Nature 2008;453:783-787.

83 Painter RC, Roseboom TJ, Bleker OP: Prenatal exposure to the Dutch famine and disease in later life: an overview. Reprod Toxicol 2005;20:345-352.

84 van Abeelen AF, et al: Famine exposure in the young and the risk of type 2 diabetes in adulthood. Diabetes 2012;61:2255-2260.

85 van Abeelen AF, et al: Postnatal acute famine and risk of overweight: the Dutch Hungerwinter Study. Int J Pediatr 2012;2012:936509.

86 Druet C, et al: Prediction of childhood obesity by infancy weight gain: an individual-level meta-analysis. Paediatr Perinat Epidemiol 2012;26:19-26.

87 Gishti O, et al: Fetal and infant growth patterns associated with total and abdominal fat distribution in school-age children. J Clin Endocrinol Metab 2014, E-pub ahead of print.

-88 Zambrano E, et al: A low maternal protein diet during pregnancy and lactation has sexand window of exposure-specific effects on offspring growth and food intake, glucose metabolism and serum leptin in the rat. J Physiol 2006;571:221-230.

89 Palou M, et al: Moderate caloric restriction in lactating rats protects offspring against obesity and insulin resistance in later life. Endocrinology 2010;151:1030-1041.

90 Rolland-Cachera MF, et al: Association of nutrition in early life with body fat and serum leptin at adult age. Int J Obes (Lond) 2013;37: 1116-1122.

91 Gunther AL, Buyken AE, Kroke A: Protein intake during the period of complementary feeding and early childhood and the association with body mass index and percentage body fat at $7 \mathrm{y}$ of age. Am J Clin Nutr 2007;85: 1626-1633.

92 Gunther AL, et al: Early protein intake and later obesity risk: which protein sources at which time points throughout infancy and childhood are important for body mass index and body fat percentage at $7 \mathrm{y}$ of age? Am J Clin Nutr 2007;86:1765-1772.

93 Gibson S, Neate D: Sugar intake, soft drink consumption and body weight among British children: further analysis of National Diet and Nutrition Survey data with adjustment for under-reporting and physical activity. Int J Food Sci Nutr 2007;58:445-460.

94 Overby NC, et al: High intake of added sugar among Norwegian children and adolescents. Public Health Nutr 2004;7:285-293.

$\$ 95$ Parnell W, et al: Exploring the relationship between sugars and obesity. Public Health Nutr 2008;11:860-866.
Nutritional Challenges and Opportunities during Weaning and in Young Childhood
Ann Nutr Metab 2014;64:284-293 DOI: $10.1159 / 000365036$ 